\title{
Legitimising EU Governance through Performance
} Assessment Instruments

European Indicators for a Judicial Administration Policy

\section{Bartolomeo Cappellina}

\section{(Q) OpenEdition}

\section{Journals}

Electronic version

URL: http://journals.openedition.org/irpp/1023

DOI: 10.4000/irpp.1023

ISSN: 2706-6274

\section{Publisher}

International Public Policy Association

Printed version

Date of publication: 1 September 2020

Number of pages: 141-158

ISSN: 2679-3873

\section{Electronic reference}

Bartolomeo Cappellina, "Legitimising EU Governance through Performance Assessment Instruments", International Review of Public Policy [Online], 2:2 | 2020, Online since 15 August 2020, connection on 29 January 2021. URL: http://journals.openedition.org/irpp/1023 ; DOI: https://doi.org/10.4000/irpp.1023

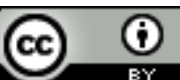

International Review of Public Policy is licensed under a Creative Commons Attribution 4.0 International. 


\section{Legitimising EU Governance through Performance Assessment Instruments European Indicators for a Judicial Administration Policy}

\section{Bartolomeo Cappellina}

Post-doc researcher at Sciences Po Grenoble, CESICE-Pacte (France)

\section{Abstract}

The article addresses the production of indicators as policy instruments in European public policy. It discusses the relevant literature on sociology of quantification and European public policy and applies this theoretical framework to the case of European judicial administration policy. Presenting the historical and institutional premises to the creation of two projects of judicial performance assessment by the Council of Europe and the European Commission, as well as their methodology, the article argues that the selection of indicators is a litmus test of debates over the strategies and institutional goals of the organisations proposing them. Connecting the previous analysis with the use of these instruments in the policy-making sphere, the article points out that evaluation tools in European policy, rather than serving merely as informative tools, produce empowerment side-effects in the policy arena for the organisations that developed them. In European judicial policy, indicators provide a sufficiently loose framework to solve vertical and horizontal cooperation problems at the international level, determine policy goals through the selection of areas of measurement and evaluation, and provide proof to influence local and national policy-makers over reforms either through lesson-drawing, persuasion or conditionality.

\section{Keywords}

policy instruments, justice, policy change, indicators, European Commission, blame avoidance 


\section{Introduction}

Since the 1980s, the previously sector-specific and economically related use of indicators has become a widespread phenomenon in almost every aspect of public governance (Espeland \& Sauder, 2007; Merry, Davis, \& Kingsbury, 2015). This article discusses the role of indicators in European public policy, depicting how they influence the balance of power between European institutions and Member States, informing from above and on certain conditions inducing policy change. It questions the case of European indicators measuring the activity of judicial systems, positing their development by the Council of Europe (CoE) and the European Union (EU) as strategically oriented to reinforce their standing in the field of judicial policy and underpin their capacity to drive change in member states.

The article is relevant for scholars in International and European public policy in at least three ways. First, following a flow of research in development studies and international relations (Davis, Fisher, Kingsbury, \& Merry, 2012; Dixon, Hood, \& Jones, 2008; Kelley \& Simmons, 2015), the article links the diffusion of indicators with the development in European states of what has been called a Neo-Liberal governmentality, or New Public Management reforms (Christensen \& Lægreid, 2011; Desrosières, 2011; Hood, 1991). The justice sector has been included in this flow and some scholars have even inferred a turn in the focus of its activity from the normativity of law to the performativity of procedures (Piana, 2014; Luhmann, 1995). Therefore, justice - a sovereign power in the classical Montesquieu's theory of check and balances, characterised by a high level of independence from the politics of its professionals - is particularly fit as a case study to show how the "quiet power of indicators" (Merry et al., 2015) operates to drive change in public policy.

Secondly, the article contributes to the discussion on the evolving nature of European public policy and the place of policy instruments therein (Howlett, 2019; Graziano \& Halpern, 2016; Dehousse, 2016). The literature on European public policy shows that executive, legislative and judicial powers, both nationally and at the European level, increasingly share their authority with regulatory agencies, where political action is blended with technical and epistemic knowledge to deal with the rising complexity of international public policy (Maggetti \& Gilardi, 2014; Dunlop, Maggetti, Radaelli, \& Russel, 2012; Radaelli, 1999). On the international scale, indicators have been linked to the framework of the evidence-based policy paradigm, which promotes the evaluation and the impact assessment of public policy through the measurement of public-sector activity and other forms of experimentation that spread in government agencies and departments all over Europe and integrated the European level itself through the "new" modes of governance (Radaelli, 2009; Sanderson, 2002).

Finally, the article is relevant to scholars focusing on the role of soft law in International and European public policy (Abbott \& Snidal, 2000; Cini, 2001; Quaglia, 2019; Terpan, 2015; Trubek \& Trubek, 2005). It suggests that international indicators as instruments of soft law can have hard and durable effects on policy strategies in the European policy-making sphere and policy change in general, especially in areas of policy in which the European institutions cannot rely on the use of hard law instruments.

\section{Methodology and Empirical Analysis}

The article is built on research that uses an atheoretical type of process tracing (George \& Bennett, 2005, p. 508), which presents the necessary steps to build a more formal explanatory model of the influence of European institutions on civil justice reforms in European countries since 2014. This article does not present the process tracing framework of the effects of dif- 
ferent policy strategies on national and local policy change, but deals with the first part of the story. The article shows how the European Commission put itself in the position of exerting influence on Member States in a field of policy that was previously beyond its remit. It does so presenting how the indicators on the performance of national judicial systems initially developed in the context of the Council of Europe ( $\mathrm{CoE}$ ) started to play an important role in shaping policy once they have been integrated in a new toolkit by the European Commission. Timing the post-crisis policy narrative focused on competitiveness with the Rule of Law crisis narrative which developed in the early 2010s over some Eastern European countries (Romania, Poland, Hungary), the Commission has been able to expand its competence on a new field of policy focusing on the previously very marginal judicial administration policy. We argue that the European judicial indicators not only helped the Commission to expand the field of European public policy in the sector of judicial administration, but also empowered the Commission position towards the Member States, altering the previously intergovernmental and national frameworks of judicial policy (Lavenex, 2015; Trauner \& Ripoll Servant, 2016).

For what concerns the triggering of actual policy change at national level, we can for the time being only rely on previous work that successfully rose to the challenge of establishing causal relations between non-binding EU stimuli and domestic change (Moumoutzis \& Zartaloudis, 2016). The results presented in this article suggest that the EU turned the CoE instruments, developed to trigger social learning among national judiciaries and governments, into a performative naming and shaming strategy, using conditionality and persuasion as mechanisms of change. However, a thorough analysis of the national policy changes is beyond the scope of this article, and we can only conclude on these European mechanisms as prominent hypotheses to guide future research dealing with the role of indicators in triggering national policy change in the judicial sector.

The analysis relies on the archives of documents produced by the European Commission for the Efficiency of Justice of the CoE (CEPEJ) and the European Commission, as well as on fieldwork undertaken at the working sessions of the CEPEJ and on interviews with members, experts and officers of the two organisations ${ }^{1}$. Survey data on the careers and commitment of these transnational experts in the field integrates the analysis to generate deeper insights into the working methods and the different backgrounds integrating these forums charged with the elaboration of the indicators under scrutiny.

The article starts by discussing the relevant literature to theoretically address the production of indicators on the European sphere and their use in European public policy. Then, the second and third sections provide insights into the historical and institutional premises to the creation of the two projects of judicial performance measurement by the CoE and the EU, as well as the methodology adopted by the two institutions to produce their judicial evaluation tools. This section shows that the selection of data and indicators is a litmus test of debates over the strategies and institutional goals of the organisations proposing them. The fourth section, connecting the previous analysis with the use of these instruments in the policy-making sphere, points out that evaluation tools in the European sphere, rather than serving merely as informative tools for policy (as the evidence-based governance paradigm proposes), produce

$1-15$ interviews lasting one to two hours were realised with CEPEJ experts and members of the secretariat, 5 interviews with officers of the European Commission, and 5 interviews with National Correspondents charged with the statistical collaboration with the CEPEJ and the European Commission. Moreover, a total of 15 days of observation at CEPEJ meetings were realised between 2014 and 2016. 32 current and former CEPEJ experts answered a survey on their career and experience as international experts. Only one European Commission official replied to the questionnaire, the others considering it inappropriate for their status of civil servants to express opinions on their work. 
secondary empowerment side-effects in the policy arena for the organisations that developed them. Even though the study of the impact of this empowerment is beyond the scope of this article, we conclude in the fifth section on the ways in which this legitimising role played by indicators on the transnational scale helps to produce change in European member states' justice systems. The development of European judicial indicators contributes consistently to the recognition of the CoE (and particularly of the CEPEJ) and the European Commission as legitimate actors in the field of judicial administration, especially for civil justice, and opens venues for actively intervening on policy change for these organisations, both within and outside EU boundaries, given the right conditions for European institutions to exercise pressure on the national authorities and professionals. This relates to similar conclusions highlighted by the European governance literature on the use of international indicators in the education policy sector (Normand, 2016; Papadimitriou, Gornitzka, \& Stensaker, 2015).

\section{Findings}

\section{Judicial indicators and European policy}

The sociology of quantification and technology of governance is a prism through which the elaboration of indicators on judicial systems as instruments serving the production of specific visions of the functioning, goals and rules of justice can be envisaged. A fundamental step in this perspective is to analyse the contexts and actors involved in their development in order to clarify the linkage between the knowledge that informed the production of indicators (Penissat \& Rowell, 2014) and the knowledge that is to be produced through them. The latter influences political decision making and frames problems as well as solutions of policy that are not socially or politically neutral (Lascoumes \& Le Galès, 2007), as they derive from a specific construction of reality that actors perform through statistics (Desrosières, 2011). On the other hand, we consider indicators in the light of the innovative public policy settings that produced them, notably taking into account the literature on 'new' European governance (Diedrichs, Reiners, \& Wessels, 2011; Eberlein \& Kerwer, 2004; Tömmel \& Verdun, 2009). Part of the literature on new modes of governance in the EU posits them on one side as a solution to the problem of decision-making in fields where one-for-all agreements are impossible, and on the other as a structure that grants the EU (and notably the European Commission) the opportunity to trigger mechanisms through which its action in policy domains that were previously out of its reach can be incorporated and legitimised (Dehousse, 2016; Tholoniat, 2010; Trubek, Cottrell, \& Nance, 2006).

The starting point of our analysis is that the necessity to 'better govern' societies through informed public policies justified a wide-spreading process of quantification of the social world (Diaz-Bone \& Didier, 2016; Muniesa \& Linhardt, 2011; Saetnan, Lomell, \& Hammer, 2011). This prism of reform, deepened by the Neo-liberal governments of the 1980s, implied in the last 30 years the construction and exploitation for policy ends of significant amounts of statistical information, allegedly easing the decision-making process through the construction of objective 'best practices' and regulatory frameworks locally, nationally or at the European level. Some authors pinpointed the facilitation of learning processes and policy adjustments that the benchmarking of these supposedly objective policy solutions enable in European public policy (Arrowsmith, Sisson, \& Marginson, 2004; Lodge, 2005). In this view, indicators - part of the toolkit of soft law instruments - contribute actively to the production of specific visions of the social world that they measure, while driving some sort of compliance from the measured towards the attributes that they measure. 
Justice, while not new to the statistical measurement of its activity (Lomell, 2011; Williams, 2011), has followed this new focus in the production of data, indexes, and indicators for public governance, becoming one of the main domains of measurement in a society of 'risks' (Beck, 1992; Saetnan et al., 2011). A societal and political pressure for higher transparency of public services driven and reinforced by New Public Management (NPM) reforms invested justice since the 1980s in the US and the 1990s in Europe. The four key processes characterising NPM - managerialisation, marketisation, privatisation and corporatisation (Galetto, Marginson, \& Spieser, 2014) - showed their effects in various reforms, from new forms of evaluation of the work of judicial professionals, to the diffusion of alternative dispute resolution methods. In this article we focus on managerialisation, defining it as that process that changed the organisational practices of justice towards the quest for higher efficiency, to be obtained through the optimisation of human and material means and the use of private-sector management tools and practices, such as the user/client approach to service processes, a market-driven control of costs and the measurement of performance to assess actions by result (Hood, 1991; Vigour, 2015).

Moreover, the initial national cross-time comparisons of performance realised in statistics departments of ministries have been followed in the 2000s by international comparisons trying to evaluate the performance of countries over various dimensions of legal systems, as their capacity to enforce human rights and the rule of law ${ }^{2}$ or their capacity to foster economic development ${ }^{3}$. A number of authors link this diffusion of managerial modes of performance measurement on the micro scale with a global turn in the relationship between knowledge and power in law and justice, which enables the "transformation of social facts of legal relevance (e.g. ordered empirical data about the rule of law) into standards of behaviour (i.e. rule of law benchmarks)" (Restrepo Amariles 2015, 12).

In the next paragraph, we highlight this link existing between the managerial turn in public policy and the production of legal indicators at the International and European level focusing on two projects of quantification of judicial systems that assess the efficiency and quality of their functioning: the 'Evaluation Report of European judicial systems' developed by the CEPEJ, and the 'EU Justice Scoreboard' of the European Commission. An emphasis on the evolution of the legal indicators included in these European projects shows how these instruments of quantification of judicial activity assumed a precise role in the governance structure of European judicial systems that goes beyond the supposedly neutral measurement of their activity, and that is of central relevance for the debate over the choice of tools and policy designs in European public policy (Howlett, 2019; Jordan, Wurzel, \& Zito, 2005).

\section{Premises for European judicial indicators: the Council of Europe at the core of the European judicial policy}

Court efficiency became a central issue in the European agenda after the opening of the jurisdiction of the European Court of Human Rights (ECtHR) to individual procedures coming from citizens denouncing a violation of their rights. In 1999, an immediate increase in the amount of appeals to the ECtHR followed this opening. Composed in great part of complaints related to supposed violations of Article 6 on fair trial, the largest category were violations of the right to a trial "within reasonable time". This immense caseload was creating a paradoxical

2 - For example, the World Justice's Project Rule of Law Index, the Freedom House Freedom in the World indicator, or the Transparency International Corruption perceptions Index.

3 - For example, World Bank Doing Business index, or the OECD's Government at a Glance report. 
situation whereby the court supposed to decide over violations of the reasonable length of trials was itself at risk of not complying with the European Convention of Human Rights (ECHR) principle (Johnsen, 2012). Contextually, in 2000, the EU adopted the Charter of Fundamental Rights $^{4}$, in which Article 47 stipulates the right to a fair trial and an effective remedy. However, the appeal framework to the Court of Justice of the EU has substantially excluded the issue of length of proceeding from its review, leaving the substantial burden of the application of fair trial principles on the shoulders of the CoE. The Committee of Ministers, its steering organ, reflected over the creation of a committee charged with the development of solutions that could help member countries to comply with Article 6 of the ECHR. Creating in 2002 the CEPEJ, the Strasbourg organisation proposed the adoption of a systemic and informative approach to guide the future judicial policies of member countries, focused on the analysis of the functioning of judicial systems, of judicial procedures' time management, and on the promotion of the quality of judicial services for the citizens (Boillat \& Leyenberger, 2008).

The first task of the CEPEJ was to collect reliable and comparable data from all CoE Member States to compare their characteristics, give insights and help reflections on the factors influencing the length of proceedings and the quality of judicial systems. To do so, in 2003, a sub-committee was created which was composed of six experts. Each member was selected by the CEPEJ Secretariat following a proposition by the Member State of the expert, its domain of specialisation, and the criteria of equal representation of gender and of regional models of judicial systems. Following the instructions of the Resolution creating the CEPEJ, the group of experts first concentrated its action on the "[examination of] results achieved by the different judicial systems by using common statistical and evaluation methods", i.e. on the creation of an area of equivalence for statistical comparison (Desrosières, 2011). A Dutch court management expert and member of the group produced a study of the existing frameworks of evaluation of judicial activity. The Dutch and English frameworks of court evaluation, created with the NPM reforms during the late 1990s, and the framework used by the World Bank to compile its justice sector database, were used for proposing a set of indicators. However, part of the group considered this first project "too bureaucratic and detailed for member countries to be filled ${ }^{6}$. Though, rather than the intergovernmental bargaining pointed out as a topical tension of international committees, it was the deliberative equilibrium between conceptions of judicial systems that was at stake in the group (Joerges \& Neyer, 1997). The law professionals in the group were willing to take back control of the set of indicators to avoid it being labelled a managerial tool by their national fellows, a label that would have undermined its legitimacy among judicial professionals.

Chaired by the President of the group, a French magistrate very keen to consider the reception by member countries as an important element to guide the selection of indicators, the group composed a list of 108 indicators. The indicators included many of those initially proposed by the Dutch expert and were organised around five main themes descriptively covering the organisation of tribunals as a whole ${ }^{7}$, and excluding some advanced synthetic performance in-

\footnotetext{
4 - Jointly proclaimed in 2000 by the European Parliament, the Council of Ministers and the European Commission. 5 - Res(2002) 12 of the Committee of Ministers, Appendix 1, Article 1.

6 - Interview with a judge, member of the expert group, November 2014

7 - The five themes are: (1) the public expenditure on courts and legal aid, measuring the budget allowed to courts and access to justice; (2) the judiciary and the courts, giving data on court staff numbers and on the responsibilities over their management; (3) court performance, including only data related to the number of cases and their timeframe; (4) public prosecutors, presenting numbers and differences in the organisation of prosecutor's offices around Europe; (5) legal professionals, looking at status and numbers of actors working with the courts, such as lawyers, bailiffs and mediators.
} 
dicators such as the ratio between incoming cases and resolved cases. The first report collected answers from 40 national Ministries of Justice or Councils for the Judiciary, consulted during the process in a network of national correspondents composed of civil servants from statistics and international relations departments. The report was then made permanent at a biennial rate ameliorating its methodology and its standing among stakeholders at every new edition, through a process of addition and modification of indicators that is far from being neutral or technical, confronting traditional models of justice administration with new managerial and organisational knowledge (Cappellina, 2017a; 2017b). Notably, synthetic performance indicators were included in the third edition of the report (2008) following a switch within the members of the group that reaffirmed the mission of the CEPEJ in the following terms:

We are the Commission for the Efficiency of Justice and efficiency means the relation between input and output, efficiency means simply that. So, let us ask for the input, which means budget plus personnel. But then you have also interest in what goes out, what they are doing with these resources, what are they producing, how many cases and in which ways. It took almost one day and a night to discuss this and to persuade that methods like clearance rate and disposition time ${ }^{8}$ are not only of use, but will be politically accepted. (Interview with Central European magistrate, CEPEJ expert, December 2014).

\section{Indicators as instruments for horizontal policy learning: the seizing of European judicial indicators by the EU}

An escalating turn in the integration of judicial systems as a sector of European policy derives from two contextual targets of the European Commission. In the late 2000s, in the framework of EU enlargement and neighbouring countries' programmes, the Commission became interested in indicators to assess the progress of countries in the institutional reforms for which the EU was providing financial support and policy advice, relying on a networked approach associating multiple actors of the field of Rule of Law promotion, such as the CoE itself and a variety of NGOs (Coman, 2014). The expertise of CEPEJ was particularly mobilised in the context of judicial administration reforms in candidate countries (Dallara \& Piana, 2015).

Secondly, Economic Adjustment Programmes activated in 2010 to tackle the economic crisis in some EU countries showed some evidence that shortcomings in the functioning of justice increased the negative growth spiral and undermined the confidence of citizens and enterprises in the justice institutions (European Commission, 2013b). For this reason, in 2011, national judicial reforms became an integral part of these programmes. Moreover, in 2012, in a debate at the European Parliament, Viviane Reding - the Directorate General Justice Commissioner announced that because of serious situations concerning the rule of law in the EU countries, it was noticed that the EU was lacking 'effective mechanisms [...] to enforce respect for the rule of law more generally and more systematically ${ }^{9}$. This statement had been at the centre of internal discussions in the European Commission towards possible solutions that could be effective in killing two birds with one stone: ensuring the respect of the rule of law in the EU and, in the context of the economic crisis, fostering economic growth through effective justice systems. Admitting that infringement procedures are too technical and too slow to react to high-risk situations concerning the rule of law, and considering the Article 7 TEU procedure as a nuclear

\footnotetext{
8 - The first can be used to see if the courts are keeping up with the number of incoming cases without increasing the backlog, the second calculates the hypothetical number of days that are necessary for a new incoming case to be treated considering the backlog of cases.

9 - Viviane Reding, DG Justice Commissioner intervention at the European Parliament debates on 12 September 2012, Strasbourg.
} 
option $^{10}$, the Commissioner Reding proposed to 'add to the economic and social benchmark in the European Semester a new mechanism for measuring, comparing and benchmarking the strength, efficiency and reliability of the justice systems in all Member States ${ }^{11}$.

The Commissioner proposal referred to the creation of a document in the form of an annual scoreboard resuming data on judicial systems in the EU to pinpoint malfunctions in their organisation and design concrete reform venues with member countries under the European Semester recommendations programme. In late 2012, DG Justice, as chef de file of the project, was charged with the coordination of the drafting of the 'EU Justice Scoreboard' within the Commission. A newly set unit created in January 2013 and composed of a dozen legal experts hired from other departments of the Commission was charged with the coordination of all Commission activities related to judicial organisation reforms, i.e. monitoring of judicial reforms in the European Semester, and the new-born EU Justice Scoreboard. Most of them are lawyers with no experience in the specific field of socio-legal measuring and evaluation ${ }^{12}$. The modus operandi for the Scoreboard involves substantial contributions from other departments of the Commission, notably from DG ECFIN for statistical assistance ${ }^{13}$. Moreover, data used to compile the Scoreboard comes mainly from external sources such as CEPEJ, the European Network of Councils for the Judiciary, the World Bank, the World Economic Forum and the World Justice Project.

The institutional setting and policy venue that gave birth to the EU Justice Scoreboard also has an impact on the choice of its indicators. The Commission considers the effectiveness of justice systems as one of the cornerstones of the rule of law principle ${ }^{14}$. The three macro-indicators defining this concept in the framework of the EU internal and external action are quality, independence, and efficiency of justice (European Commission, 2014b). However, each of these principles can be defined in various ways as the long discussions inside the CoE and in other European and international networks of justice professionals confirm (Dallara \& Piana, 2015). In the Scoreboard, quality of justice indicators are structured around the monitoring and evaluation of court activities, the information technology systems for courts, the alternative dispute resolution methods and the training of judges. These elements are stipulated as central by previous work of $\mathrm{CoE}$ advisory bodies ${ }^{15}$. Independence of justice is divided between perception and structural elements (councils for the judiciary, role of ministries...). Independence was a mandatory dimension to consider in relation to the problems seen in some Eastern European countries, and was instrumental to include justice professionals in the Scoreboard, through the collection of data on structural independence furnished by national Councils for the Judiciary. Efficiency of justice is considered as judicial procedures' input-output performance as provided by the CEPEJ. Moreover, the Scoreboard includes some sectorial data on the length of proceedings for cases relevant for the economic environment, such as insolvency and competition law, derived from other sources such as the World Bank's Doing Business and some field studies produced by private consultants and financed by the Commission. This choice has been influenced by internal and external work that linked the efficiency of civil justice institutions

\footnotetext{
10 - This article depicts the possibility for the Council of the EU to suspend the rights of a Member State as consequence of repeated breaches of the values of human dignity, freedom, democracy, equality, the rule of law and respect for human rights, enforced under art. 2 of the TEU.

11 - Viviane Reding, DG Justice Commissioner intervention at the European Parliament debates on 12 September 2012, Strasbourg.

12 - Interview with DG Justice policy officer, 25/01/15.

13 - Interview with DG ECFIN policy officer, 21/05/16.

14 - For a discussion of this central but volatile concept, see Carothers 2006; Coman 2016; Dallara and Piana 2015.

15 - See in particular, CCJE opinion n. 6 (2004) on fair trial within a reasonable time.
} 
to economic growth indicators (Bianco, Giacomelli, Giorgiantonio, Palumbo, \& Szego, 2007; Lorenzani \& Lucidi, 2014; Palumbo, Giupponi, Nunziata, \& Mora Sanguinetti, 2013).

\section{Indicators as policy change drivers: from information to influence}

The traditional guiding principles of judicial activity (independence and impartiality) and the modernist principles derived from the affirmation of a market-driven logic in public policy (organisational performance, quality management) are present both in the CEPEJ and the EU Commission indicators. However, the synthesis has been realised in distinct ways by the two organisations because of the different institutional settings, goals pursued and stakeholders targeted. In CEPEJ, starting from Article 6 ECHR, the confrontation between actors supporting one or the other view of how judicial systems effectively accomplish their mission for society shaped a detailed and didactic instrument co-produced by judicial actors themselves to spur social learning. Otherwise, the Commission searches for a difficult balance between the interest of market actors and the interest of judicial professionals. As we have shown, the result is a Janus Bifrons which on one hand follows the CEPEJ approach, proposing a picture to guide the reflection of policy-makers at all levels of the governance of judicial systems, including the traditional ones, but on the other looks at investors pointing implicitly to those systems that are more attractive for their activities. The internal and sectorial (justice) perspective of the CEPEJ is then associated with an external and transversal (economy) approach by the Commission.

In both cases, we argue that the use of indicators serves a two-fold objective: (1) Defining an indicator translates a theoretical concept in measurable dimensions. This operational definition is conceived as an aid to enforce the concept on the field through the definition of a benchmark that can guide the relationship between the measuring and the measured. (2) In this relationship, indicators reinforce the capacity of the measuring institution, which can use them to legitimise demands and decisions or to put emphasis on specific sides of policy problems (e.g. using the concept of fair trial and effective remedy to focus on issues of case management in the judicial administration).

The two judicial performance assessment reports differ in many ways in their content as they share only a limited number of indicators related to the efficiency of the justice systems (such as the number of judges, the clearance rate and disposition time), which are moreover presented in a different light in the two performance assessment instruments (Mohr \& Contini, 2014). A precise analysis of all the indicators included in them or an evaluation of their statistical reliability have been already presented by other scholars and are beyond the scope of this article ${ }^{16}$. Here, we complement these previous analyses arguing that these performance assessment instruments can be distinguished over two main aspects from a policy process perspective: the institutional goals and the type of policy arena that produced them.

Increasing the self-awareness of the Member States over judicial quality is the main objective of the CEPEJ, while the EU Commission pursues its overarching economic objectives reflecting the idea that the rule of law is a constitutive element of a business-attractive country. Concerning arenas, the CEPEJ closely resembles an epistemic community, where in a bottom-up perspective different ideas and conceptualisations of judicial systems are confronted one to another to produce shared knowledge (Haas, 1992). The Commission activities on judicial systems match the framework of an open method of coordination (OMC) in disguise (Arrowsmith et al., 2004; Radaelli, 2003). While the benchmarking and social learning objectives are displayed,

16 - For an analysis of the content of these European data collections and the difficulties related to the comparisons they make, see Boillat \& Leyenberger, 2008; Dori, 2015; Fabri, 2017. 
the participatory governance model of OMC is nuanced. If an arena for open discussion with Member States exists in the form of annual meetings with national correspondents, where technical issues and best practices are shared, the control over the tool is firmly in the hands of the Commission. Through it, the Commission nourishes a discourse about what constitutes an effective judicial system and exercises control over the conformity of Member States to this erratic standard.

The differences in the evaluation of judicial systems between the CEPEJ and the Commission emerge as well in the influence towards national and local policy. The CEPEJ report and the EU Justice Scoreboard helped to create a transnational network governance structure between national judicial systems, international (and supranational) organisations and transnational networks of professionals. This system of governance on one side participated in the shaping and developing of the two reports, and on the other it has been the channel through which the other activities of the two organisations may reach interested stakeholders. In this sense, indicators perform a catalyser effect as they help the recognition of the organisation producing them in the field of policy through their mediatisation. The identification of the organisation producing the indicators as a trustable expert in the field of policy concerned makes easier the circulation of other instruments such as best practices and other forms of benchmarks.

Table 1. Goals, stakeholders and policy scope of the CEPEJ Report and the EU Justice Scoreboard as policy instruments

\begin{tabular}{|l|l|l|l|l|}
\hline Instrument & Main goals & $\begin{array}{l}\text { Targeted } \\
\text { stakeholders }\end{array}$ & $\begin{array}{l}\text { Policy } \\
\text { influence }\end{array}$ & $\begin{array}{l}\text { Policy change } \\
\text { mechanism }\end{array}$ \\
\hline $\begin{array}{l}\text { CEPEJ } \\
\text { Report }\end{array}$ & $\begin{array}{l}\text { Comparability } \\
\text { Base for problem } \\
\text { identification }\end{array}$ & $\begin{array}{l}\text { Justice } \\
\text { professionals } \\
\text { Councils and } \\
\text { Schools for the } \\
\text { judiciary } \\
\text { Policy makers }\end{array}$ & Horizontal & $\begin{array}{l}\text { Performance } \\
\text { assessment } \\
\text { convergence } \\
\text { Performance } \\
\text { feedbacks } \\
\text { learning }\end{array}$ \\
\hline $\begin{array}{l}\text { EU Justice } \\
\text { Scoreboard }\end{array}$ & $\begin{array}{l}\text { Justify policy } \\
\text { pressure } \\
\text { Classify RoL } \\
\text { performance }\end{array}$ & $\begin{array}{l}\text { Member States' } \\
\text { governments } \\
\text { Economic actors } \\
\text { Councils for the } \\
\text { judiciary }\end{array}$ & Vertical \\
\hline
\end{tabular}

Source: The Author

\section{Different approaches of policy influence for different mechanisms of policy change}

As Table 1 shows, the two institutions exert influence on national policy through different patterns and mechanisms of change. The CEPEJ relies on a networked approach exercising mainly a symbolic pressure for change through instruments, allowing diagnoses and drawing lessons from principles or practices of organisation from below, i.e. from the states or judicial professionals, but as well through cooperation with other actors of the field, such as the European Commission. 
The CEPEJ report is available on the site of the CoE and it is the object of a press conference at its publication. Moreover, it is diffused at national and local level in two ways. One is through the hierarchical chain linking the CoE country representatives to their national authorities. The other is through the action of the national members of CEPEJ that produced it. This implies that the use of indicators spreads through national authorities and jurisdictions at different degrees depending on the capacity of the national members to reach the important stakeholders, and on the level of interest that judicial reform has in the policy agenda of the country. The Scoreboard is publicised through the media division of the Commission and it is sent to the national authorities of the Member States for notice. Both represent trademarks for the organisations producing them as they are their most well-known activities in the judicial administration policy sector.

For instance, while a direct effect of transnational indicators of performance assessment is difficult to prove, actors in the field often point out the inspirational role played by comparative data, as has been the case for the recent trend of judicial map reforms. Based on the necessity of cutting budgets and the relation observed between increasing backlogs and the excessive number of courts, the results of the first reforms realised in Denmark, France and Belgium before 2010, subsequently inspired similar changes in other countries such as Austria, Italy and the Netherlands (European Commission, 2015). The CEPEJ report is also widely used by either governments or associations of magistrates to pinpoint the strengths or weaknesses of their judicial systems during policy debates over reform ${ }^{17}$. In some cases, it is used in ways that go beyond the intentions of its producers, showing the nature of the policy instrument of the report (Lascoumes \& Le Galès, 2007). Indicators alone do not provide specific representations of social reality. It is the interpretation by social actors that gives them a specific significance. To the despair of CEPEJ experts, in 2010 the UK government cut its legal aid funds and justified its choice with CEPEJ data, proving that the UK had the biggest budget in Europe allocated to it. It is arguable that the use of CEPEJ data done by the EU Commission falls in the same category in the opinion of many CEPEJ members who criticise the economic-oriented approach of the Scoreboard.

The report worked as well as the catalyser of attention over CEPEJ and its other activities. Within CEPEJ, the SATURN Centre for judicial time management (another expert group) develops benchmarking tools for the management of court timeframes. These practical tools found interested audiences in courts at the national and local level, which lead CEPEJ to participate in various cooperation programmes within specific courts or with national authorities. In these programmes, experts realise local studies on the needs and problems of courts and propose solutions based on the tools developed within CEPEJ ${ }^{18}$. Realised mainly in Eastern Europe and in EU neighbouring countries (e.g. Azerbaijan, Morocco), EU candidate countries have also been in demand of CEPEJ cooperation as part of institutional reforms requested to obtain EU membership (e.g. Albania and Croatia $^{19}$ ). Western European courts showed less

17 - A debate over the contested law that reduced the vacations of Italian magistrates saw the national association of magistrates use CEPEJ data to prove that Italian judges do not have a problem of productivity and that the problems of the system had to be identified elsewhere. However, the proposed alternatives of limiting the excessive quantity of incoming cases and intervening on the extremely high number of lawyers did not move the government from its initial intentions.

18 - The work of the group consist of guidelines, checklists and best practices, covering almost every aspect of judicial administration. Depending on the needs of local courts, some specific solutions are chosen out of the array of best practices and are proposed by CEPEJ experts to local professionals in meetings and trainings.

19 - The Commission, in 2006, deemed Croatia as in need of considerable efforts in the sectors of judiciary and fundamental rights, and justice, freedom and security. At the time of its access to the EU in 2013, its status on these domains was "generally aligned with the acquis". The CEPEJ participates nowadays in a large project of diffusion of best practices for court management financed by Norway grants throughout all Croatian courts. 
interest in CEPEJ expertise. However, examples of cooperation involving local change entrepreneurs in Italian courts validating their backlog cutting tools under the umbrella of CEPEJ expertise (Barbuto, 2013) confirm the validity of lesson-drawing for some Western European countries as well. These examples show that the network approach represents a fundamental resource for CEPEJ to produce effective change in judicial systems. Leaving the initiative for cooperation to the will of local and national authorities to draw lessons from European best practices (Rose, 1991), the CEPEJ generally finds receptive actors when it is requested on the field in programmes. These programmes, in Rose's terms, take the form of synthesis ('combining familiar elements from programs in a number of different places to create new programs') or inspiration ('using programs elsewhere as an intellectual stimulus to develop a novel program') (1993, p. 30). In contrast, the horizontal structure of the network approach is also an important reason to explain the limited capacity of CEPEJ to promote cooperation on a larger scale (Coen \& Thatcher, 2008).

Inversely, if the European Commission developed expertise in the field of judicial administration relying on a network of other actors (e.g. the CEPEJ for the efficiency of justice, and the European Network of Councils for the Judiciary for the independence of justice), it is a hierarchical top-down relationship that better describes the ways in which the Commission tries to push through its policy solutions towards Member States in the judicial administration policy field. The performance assessment of countries is used to persuade Member States to change their practices and norms in a direction that would allow them to achieve better results in the indicators, avoiding the blame and the economical disincentives from investors that come with low performances in indicators such as the disposition time for a proceeding or the capacity to enforce a contract in the country's judicial system. In this framework, the European Commission intervention capacity to foster change in its position of guardian of the treaties and growth in the European Economic Area is higher in the countries that are violating the treaties or struggling with growth, but lower to influence 'well-behaving' states. In the framework of the European Semester, while not being the only source of information, the Scoreboard is used to study and justify annual country reports to the Member States ${ }^{20}$. Moreover, the Commission exercises policy influence through country-specific recommendations and meetings with Ministries, Councils for the Judiciary, judges and lawyers in member countries ${ }^{21}$. Therefore, while being a non-binding and not evenly influential tool, the Scoreboard allows the Commission to open tables of discussion with member countries to exercise vertical pressure on national and local policies.

This pressure can take either the form of conditionality in the cases in which the recommendations are part of Economic Adjustment Programmes (e.g. Portugal), or the form of persuasion and incentive for those countries that are not under financial redressing programmes (e.g. Italy). For these countries, the adoption of the recommendations coming from the Commission relies on the appropriateness that they attribute to them as solutions to ameliorate the functioning of their national judicial system (Schimmelfennig \& Sedelmeier, 2004). The recommendations addressed to countries are based on the identification of problems and solutions. The first ones are pinpointed by the Scoreboard data and by meetings with national stakeholders. Solutions are built on the contextualisation of European practices in the field concerned by the recommendation. These European practices come either from other EU countries or the

20 - In 2016, 14 countries presented some paragraphs delineating the state of play and possible interventions in the functioning of their justice system and insolvency (Interview, EU Commission officer 3).

21 - Not all the countries with a chapter on justice in the country reports have country-specific recommendations. The latter ones are issued taking in consideration of the severity of the situation in other policy sectors as well. 
European best practices elaborated in transnational institutions such as the CEPEJ, the CCJE or ENCJ ${ }^{22}$. Moreover, the contributions coming from research and think tanks working in the field are also included. The case of Italian reforms is again illustrative of these dynamics.

Since 2013, the country reports and recommendations addressed to Italy put an emphasis on the need to reduce the input and the backlog of court cases. Recognised as hard working ${ }^{23}$, Italy is advised to intervene in the high level of litigation. The 2013 country report states that "out-of-court dispute settlements carry a strong potential for reducing the length of civil proceedings and alleviating judges' and courts' workload" (European Commission, 2013a). Italy has since then adopted measures to make pre-trial mediation compulsory in some specific matters in civil and commercial procedures (European Commission, 2014a). However, the 2016 country report evaluates negatively the impact of these reforms, suggesting that the "limited success of the mediation scheme introduced in 2013 [...] may call into question the compulsory approach to mediation" (European Commission, 2016). This example shows that while the Commission can pinpoint areas for intervention, it cannot draw countries to specific solutions. For what concerns the reduction of courts' backlog, the use of clearance rates and disposition time indicators has a central role in the evaluation of the measures undertaken by Italy.

Every country report considers the overall impact of the reforms undertaken by Italy under the scope of these two indicators. While acknowledging the efforts put in place by judges, with very high clearance rates, the limited reduction of disposition times is used to recommend a continuation of working on reforms to reduce the court backlog ${ }^{24}$. The adoption of the "first-infirst-out" rule permitting the processing of the most ancient cases in order to reduce the overall disposition time is indicated as a measure that "could have positive effects by addressing one of the most critical challenges in the justice system" (European Commission, 2016). This practice was discussed and promoted by CEPEJ in a cooperation programme with the Tribunal of Turin in 2008 (Dallara \& Piana, 2015). The registration of cases by year was nationalised in 2009 and the promotion of the president of the Turin court to the President of the Court of Appeal of Turin allowed him to diffuse the practice to the whole Piedmont-Val d'Aosta regions (Barbuto 2013). The promotion of the president of the court to a leading role in the Ministry of Justice, and its inclusion in a 2007-2013 EU Commission funded nation-wide programme of practices directed to the digitisation of civil trials and organisational and statistical reliability improvements in courts (Vecchi 2013) lead to its wider adoption, although not on a mandatory basis. The choice of disposition time as an indicator of the Scoreboard reinforced the capacity of the Commission to put pressure on Member States' governments over reforms.

As has been hypothesised in previous publications, the EU Justice Scoreboard not only has the potential to affect the division of competences between Member States and supranational institutions in the domain of the rule of law and administration of justice (Strelkov 2019), it already does so.

\footnotetext{
22 - Consultative Council of European Judges (Council of Europe) and European Network of Councils for the Judiciary, respectively.

23 - In the 2016 country report for Italy, it is stated that: "Since 2009, the total number of cases pending in courts has fallen consistently thanks to high clearance rates in both first and second instance courts, in particular regarding civil and commercial litigious cases" (European Commission, 2016).

24 - While being a prism of reform of Italian judiciary since at least 2001 with the Legge Pinto on the compensation for the unreasonable length of procedures, the focus on reducing the backlog of cases has increased since 2011 (Piana and Verzelloni 2016).
} 


\section{Conclusion}

The puzzle at the origin of this paper was twofold. In the first place, the article depicts the European fabric of transnational indicators of judicial evaluation to show that the choice of using indicators as proxies of the activity of jurisdictions answers instrumental needs. The selective process of indicators on one side creates a space of equivalence between European judicial systems, and on the other targets specific goals, linked with the overall mission of the institutions selecting them. The microanalysis of the actors involved in the process highlights the tensions between different conceptualisations of the judicial activity as proposed by professionals more or less familiar with the use of performance-oriented indicators. Secondly, the paper links the production of indicators to their use in European public policy. Presenting the uses that indicators have in the multi-layered network governance of judicial systems, the paper proves that the quantification of social reality produced by indicators has effects that go beyond the expectations and the control of the actors that shaped them. The example of the side effects produced by the CEPEJ report, both in national reforms and through the nurturing of a powerful competitor in the field of evaluation and governance of European judicial systems, illustrates these contrasted dynamics. This last example illustrates that the potential of indicators is relevant in three main aspects: providing a sufficiently loose framework to solve vertical and horizontal cooperation problems at the international level; determining policy goals through the selection of areas of measurement and evaluation, and; providing proof to influence local and national policy-makers over reforms either through lesson-drawing, persuasion or conditionality. In future research, these results on the genesis of a European field of judicial administration policy need to be put into perspective through further and more theoretically informed analysis of the transnational mechanisms behind local policy change.

\section{Bibliography}

Abbott, K. W., \& Snidal, D. (2000). Hard and Soft Law in International Governance. International Organization, 54(3), 421-456.

Arrowsmith, J., Sisson, K., \& Marginson, P. (2004). What can 'benchmarking' offer the open method of co-ordination? Journal of European Public Policy, 11(2), 311-328.

Barbuto, M. (2013). Court management. Il programma Strasburgo. In M. Sciacca, L. Verzelloni, \& G. Miccoli (Eds.), Giustizia in bilico (pp. 555-585). Roma: Aracne.

Beck, U. (1992). Risk Society: Towards a New Modernity. London: Sage.

Bianco, M., Giacomelli, S., Giorgiantonio, C., Palumbo, G., \& Szego, B. (2007). La durata (eccessiva) dei procedimenti civili in Italia: offerta, domanda o rito? Rivista Di Politica Economica, 97(5), 3-54.

Boillat, P., \& Leyenberger, S. (2008). L'administration et l'évaluation du service public de la justice, vu du Conseil de l'Europe. Revue Française d'Administration Publique, 125(1), 55-66.

Cappellina, B. (2017a). Évaluer l'administration de la justice dans les pays européens. Une co-construction entre Union européenne et Conseil de l'Europe. Revue Française d'Administration Publique, 161(1), 59-72.

Cappellina, B. (2017). Quantifier la qualité de la justice entre droits de l'homme et modernisation. Revue Française de Socio-Économie, 19(2), 27-46. 
Carothers, T. (Ed.). (2006). Promoting the Rule of Law Abroad: In Search of Knowledge. Washington DC: Carnegie Endowment for International Peace.

Christensen, T., \& Lægreid, P. (2011). Democracy and administrative policy: contrasting elements of New Public Management (NPM) and post-NPM. European Political Science Review, 3(1), 125-146.

Cini, M. (2001). The soft law approach: Commission rule-making in the EU's state aid regime. Journal of European Public Policy, 8(2), 192-207.

Coen, D., \& Thatcher, M. (2008). Network Governance and Multi-level Delegation: European Networks of Regulatory Agencies. Journal of Public Policy, 28(1), 49-71.

Coman, R. (2014). The normative power of the EU and contentious Europeanization: The case of judicial politics. Journal of European Integration, 36(6), 533-548.

Coman, R. (2016). Strengthening the Rule of Law at the supranational level: The rise and consolidation of a European network. Journal of Contemporary European Studies, 24(1), 171-188.

Dallara, C., \& Piana, D. (2015). Networking the Rule of Law. How Change Agents Reshape the Judicial Governance in the EU. London: Ashgate.

Davis, K. E., Fisher, A., Kingsbury, B., \& Merry, S. E. (Eds.). (2012). Governance by Indicators. Oxford: Oxford University Press.

Dehousse, R. (2016). Has the European Union moved towards soft governance? Comparative European Politics, 14(1), 20-35.

Desrosières, A. (2011). Words and Numbers. For a Sociology of the Statistical Argument. In A. R. Sætnan, H. M. Lomell, \& S. Hammer (Eds.), The Mutual Construction of Statistics and Society (pp. 41-63). New York: Routledge.

Diaz-Bone, R., \& Didier, E. (2016). The Sociology of Quantification -- Perspectives on an Emerging Field in the Social Sciences. Historical Social Research, 41(2), 7-26.

Diedrichs, U., Reiners, W., \& Wessels, W. (2011). New modes of governance policy. Developments and the hidden steps of EU integration. In A. Héritier \& M. Rhodes (Eds.), New Modes of Governance in Europe: Governing in the Shadow of Hierarchy (pp. 19-47). London: Palgrave Macmillan.

Dixon, R., Hood, C., \& Jones, L. R. (2008). Ratings and Rankings of Public Service Performance: Special Issue Introduction. International Public Management Journal, 11(3), 253-255.

Dori, A. (2015). The EU Justice Scoreboard - Judicial Evaluation as a New Governance Tool. MPILux Working Paper, 2, 1-35.

Dunlop, C. A., Maggetti, M., Radaelli, C. M., \& Russel, D. (2012). The many uses of regulatory impact assessment: A meta-analysis of EU and UK cases. Regulation and Governance, 6(1), 23-45.

Eberlein, B., \& Kerwer, D. (2004). New governance in the European Union: a theoretical perspective. Journal of Common Market Studies, 42(1), 121-142.

Espeland, W. N., \& Sauder, M. (2007). Rankings and Reactivity: How Public Measures Recreate Social Worlds. American Journal of Sociology, 113(1), 1-40.

European Commission. (2013a). Country Reports 2013: Italy. Bruxelles: European Commission.

European Commission. (2013b). The 2013 EU Justice Scoreboard. Bruxelles: European Commission Directorate-General for Justice.

European Commission. (2014a). Country Reports 2014: Italy. Bruxelles: European Commission. 
European Commission. (2014b). The 2014 EU Justice Scoreboard. Bruxelles: European Commission Directorate-General for Justice.

European Commission. (2015). The 2015 EU Justice Scoreboard. Bruxelles: European Commission Directorate-General for Justice.

European Commission. (2016). Country Reports 2016: Italy. Bruxelles: European Commission.

Fabri, M. (2017). Methodological Issues in the Comparative Analysis of the Number of Judges, Administrative Personnel, and Court Performance Collected by the Commission for the Efficiency of Justice of the Council of Europe. Oñati Socio-Legal Series, 7(4), 616-639.

Galetto, M., Marginson, P., \& Spieser, C. (2014). Collective bargaining and reforms to hospital healthcare provision: A comparison of the UK, Italy and France. European Journal of Industrial Relations, 20(2), 131-147.

Haas, P. M. (1992). Introduction: Epistemic communities and international policy coordination. International Organization, 46(1), 1-35.

Hood, C. (1991). A public management for all seasons? Public Administration, 69(1), 3-19.

Howlett, M. (2019). Procedural policy tools and the temporal dimensions of policy Design: Resilience, robustness and the sequencing of policy mixes. International Review of Public Policy, 1(1), 27-45.

Joerges, C., \& Neyer, J. (1997). From Intergovernmental Bargaining to Deliberative Political Processes: The Constitutionalisation of Comitology. European Law Journal, 3(3), 273-299.

Johnsen, J. T. (2012). The European Commission for the Efficiency of Justice (CEPEJ) - Reforming European Justice Systems - 'Mission Impossible?' International Journal for Court Administration, 4(3), 1-19.

Jordan, A., Wurzel, R. K. W., \& Zito, A. (2005). The Rise of 'New' Policy Instruments in Comparative Perspective: Has Governance Eclipsed Government? Political Studies, 53(3), 477-496.

Kelley, J. G., \& Simmons, B. A. (2015). Politics by number: indicators as social pressure in International Relations. American Journal of Political Science, 59(1), 55-70.

Lascoumes, P., \& Le Galès, P. (2007). Introduction: Understanding Public Policy through Its Instruments? From the Nature of Instruments to the Sociology of Public Policy Instrumentation. Governance, 20(1), 1-21.

Lodge, M. (2005). The importance of being modern: international benchmarking and national regulatory innovation. Journal of European Public Policy, 12(4), 649-667.

Lomell, H. M. (2011). Making Sense of Numbers: The Presentation of Crime Statistics in the Oslo Police Annual Reports 1950-2008. In A. R. Saetnan, H. M. Lomell, \& S. Hammer (Eds.), The Mutual Construction of Statistics and Society. New York: Routledge.

Lorenzani, D., \& Lucidi, F. (2014). The economic impact of civil justice reforms. European Commission Economic Papers, 530.

Luhmann, N. (1995). Social Systems. Stanford: Stanford University Press.

Maggetti, M., \& Gilardi, F. (2014). Network governance and the domestic adoption of soft rules. Journal of European Public Policy, 21(9), 1293-1310.

Merry, S. E., Davis, K. E., \& Kingsbury, B. (Eds.). (2015). The Quiet Power of Indicators. Cambridge: Cambridge University Press. 
Mohr, R., \& Contini, F. (2014). Conflicts and Commonalities in Judicial Evaluation. Oñati SocioLegal Series, 4(5), 843-862.

Moumoutzis, K., \& Zartaloudis, S. (2016). Europeanization mechanisms and process tracing: a template for empirical research. Journal of Common Market Studies, 54(2), 337-352.

Muniesa, F., \& Linhardt, D. (2011). Trials of explicitness in the implementation of public management reform. Critical Perspectives on Accounting, 22(6), 550-566.

Normand, R. (2016). The Changing Epistemic Governance of European Education. Springer.

Palumbo, G., Giupponi, G., Nunziata, L., \& Mora Sanguinetti, J. (2013). The economics of civil justice: new cross-country data and empirics. OECD Economics Department Working Papers, 1060.

Papadimitriou, A., Gornitzka, Å., \& Stensaker, B. (2015). Designed Diffusion? The Impact of an EU Instrument for Public Management Reform in the Western Balkans. Journal of European Integration, 37(6), 629-647.

Penissat, E., \& Rowell, J. (2014). The Creation of a European Socio-economic Classification: Limits of Expert-driven Statistical Integration. Journal of European Integration, 37(2), 281-297.

Piana, D., Verzelloni, L. (2016). Dal centro disperso al centro ritrovato? Riflessioni a partire dalle riforme della giustizia in Italia. Quaderni di scienza politica, 23(2), 37-264.

Piana, D. (2014). Retour à Glasgow: normativité, performativité et gouvernance du judiciaire en Europe. In B. Frydman \& A. Van Waeyenberge (Eds.), Gouverner par les standards et les indicateurs. Bruxelles: Bruylant.

Quaglia, L. (2019). The politics of state compliance with international "soft law" in finance. Governance, 32(1), 45-62.

Radaelli, C. M. (1999). The public policy of the European Union: whither politics of expertise? Journal of European Public Policy, 6(5), 757-774.

Radaelli, C. M. (2003). The code of conduct against harmful tax competition: open method of coordination in disguise? Public Administration, 81(3), 513-531.

Radaelli, C. M. (2009). Measuring policy learning: regulatory impact assessment in Europe. Journal of European Public Policy, 16(8), 1145-1164.

Restrepo Amariles, D. (2015). Legal indicators, global law and legal pluralism: an introduction. The Journal of Legal Pluralism and Unofficial Law, 47(1), 9-21.

Rose, R. (1991). What is Lesson-Drawing? Journal of Public Policy, 11(1), 3-30.

Rose, R. (1993). Lesson-Drawing in Public Policy. Chatham: Chatham House.

Saetnan, A. R., Lomell, H. M., \& Hammer, S. (Eds.). (2011). The mutual construction of statistics and society. New York: Routledge.

Sanderson, I. (2002). Evaluation, policy learning and evidence-based policy making. Public Administration, 80(1), 1-22.

Schimmelfennig, F., \& Sedelmeier, U. (2004). Governance by conditionality: EU rule transfer to the candidate countries of Central and Eastern Europe. Journal of European Public Policy, 11(4), 661-679.

Strelkov, A. (2019). EU Justice Scoreboard: a new policy tool for “deepening” European integration? Journal of Contemporary European Studies, 27(1), 15-27.

Terpan, F. (2015). Soft Law in the European Union-The Changing Nature of EU Law. European Law Journal, 21(1), 68-96. 
Tholoniat, L. (2010). The Career of the Open Method of Coordination: Lessons from a 'Soft' EU Instrument. West European Politics, 33(1), 93-117.

Tömmel, I., \& Verdun, A. (Eds.) (2009). Innovative Governance in the European Union: The Politics of Multilevel Policymaking. London: Lynne Rienner.

Trubek, D. M., Cottrell, P., \& Nance, M. (2006). 'Soft Law,' 'Hard Law,' and European integration: toward a theory of hybridity. In J. Scott \& G. de Búrca (Eds.), New Governance and Constitutionalism in Europe and the US (pp. 65-107). Oxford: Hart.

Trubek, D. M., \& Trubek, L. G. (2005). Hard and soft law in the construction of social Europe: the role of the open method of co-ordination. European Law Journal, 11(3), 343-364.

Vecchi, G. (2013). Systemic or Incremental Path of Reform? The Modernization of the Judicial System In Italy. International Journal for Court Administration, 5(1), 64-87.

Vigour, C. (2015). Professions in Policy and Knowledge Transfer: Adaptations of Lean Management, and Jurisdictional Conflict in a Reform of the French Public Service. International Journal of Sociology, 45, 112-132.

Williams, C. (2011). Labelling and Tracking the Criminal in Mid-Nineteenth Century England and Wales: The Relationship Between Governmental Structures and Creating Official Numbers. In A. R. Saetnan, H. M. Lomell, \& S. Hammer (Eds.), The Mutual Construction of Statistics and Society. New York: Routledge. 